\title{
照明器具の輝度が脳波に及ぼす影響
}

\author{
正会員 松 島 公 嗣（松下電工株式会社） \\ 専門会員 片 山就 司 (松下電工株式会社) 正会員 高 橋 良 香 (千葉大学) \\ 非会員 下 村 義 弘 (千葉大学) 非会員 岩 永 光一（千葉大学）非会員 勝 浦 哲 夫 (千葉大学)
}

\section{Effect of the Luminaire's Luminance on Human Brain Waves}

Member Koji Matsushima (Matsushita Electric Works, Ltd.), Fellow Member Syuji Katayama (Matsushita Electric Works, Ltd.), Member Yoshika Takahashi (Chiba University), Non Member Yoshihiro Shimomura (Chiba University), Non Member Koichi Iwanaga (Chiba University) and Non Member Tetsuo Katsuura (Chiba University)

KEYWORDS : luminance,luminaire,lighting design,subjective evaluation,physiological estimation

\section{1.はじめに}

新設, 改修を問わず, 照明環境の計画段階において照明器具, シ ステムに対する投資効果を問われる場合が増える傾向にある。例え ばオフィスの執務室の照明器具の具備すべき要件は, 省エネルギ 一，環境負荷への影響などがあるが，これに加えて，作業者の知的 生産性向、上に対する，照明の効果が最近クローズアップされてき た。

知的生産性を高めるための照明技術を開発するためには,照明の 影響を定量的に計測する技術開発が必要である。例えば, 照明器具 のソフト面からの性能の効果を示す心理評価の結果を, 脳波, 心電 図などの生理評価で畩付けることができるのが望ましい．

屋内照明による, 生産性向上を評価する手法は未だ確立されてい ない. 視覚機能の基礎的な閾値と実地労働の作業効率のみに依存す るのは不十分である，といわれている1)。これを補う意味で, 生理 評価を合わせた研究が行われている.

ある目的で設定した照明要件が，心理・生理的に受け入れられて いるか否かの既往研究を紹介する，例えば，杉本は照度と生理的負 担を研究し, 生理的負担が最小になる照度と, 心理的な好ましさが 最大になる照度には，ずれがあることを報告している2，佐藤仁人 らは VDT 作業を設定して執務空間での照度と平均輝度が及ぼす生 理心理的影響を評価し，生理心理的に適当な照度水準を報告してい る ${ }^{3)}$. 坂上らは，局部照明の照度比と集中感を報告している4)。し かし, オフィス執務室で広く使用されている全般照明器具の平均輝 度が，オフィス作業者の心理・生理評価に及ぼす影響を報告してい る例は無い.

筆者らの一部は, 全般照明器具の平均輝度が適切である（作業者 に対する刺激である輝度の過不足が無い）という考えと，昨今普及 している液晶ディスプレイへの映り込み防止を雨立する蛍光灯全 般照明器具を商品化した (UGR19 対応, 以下 SP 型とする).

今回, 筆者らは, 脳波（ $\alpha$ 波带域率）を指標とした検討の結果, 輝度が低すぎる場合（CRT 用グレア規制型，CRT 型とする）およ び輝度が高すぎる場合 (下面開放型)に較べて，SP 型の場合には $\alpha$
波带域率が相対的に高い傾向があることを示した.また，これら の異なる照明条件下で連続一位加算作業を行った場合の，解答数 と照明器具の輝度の関係についても検討したので速報する。

\section{2. 仮説}

心理物理評価により, ある背景輝度の前に提示された照明器具 の輝度の評価ができる，下面開放，SP 型，CRT 型などのように 反射板輝度が異なる照明器具を注視する場合, 反射板輝度が「好 ましい好ましくない」「まぶしい.まぶしくない」などという心理 評価と, 中枢神経への刺激の程度を把握する生理評価が連動すれ ば，その心理評価を裹付けることができる5).

今回は中でも，代表的な生理指標である脳波による解析を行つ た. $\beta$ 波 $(13 \sim 30 \mathrm{~Hz})$ は，開眼時に多く出現し， $\alpha$ 波 $(8 \sim 13 \mathrm{~Hz})$ は，閉眼時に多く出現する．また， $\theta$ 波 $(4 \sim 8 \mathrm{~Hz})$ は,入眠時に 多く出現するとされている，本報では，照明器具の輝度を刺激と した場合，脳波の傾向は以下の様になると仮定した.

(a)輝度が高すぎる場合， $\beta$ 波が優勢となる.

(b)輝度が適切な場合は， $\alpha$ 波が増大する.

(c)輝度が低すぎる場合， $\alpha$ 波（特に低周波領域，Low $\alpha$ 波）上 $\theta$ 波が増大する。

この仮説の概念図を図 1 に示す，オフィスでの作業者が，適度

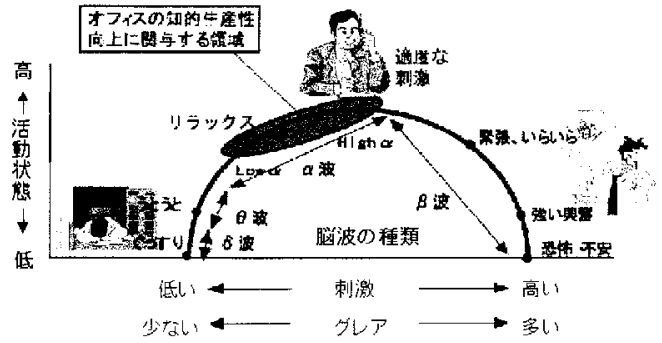

脳波と活動状態の関係

\section{図 1 脳波と知的生産性向上の仮説}

Fig. 1 Relationship between human brain wave and intellectual activity level. 
な緊張感を持ちながら他者と協調（打合せ，ミーティング）したり， 集中して思索, 作業を行える高い活動状態が維持できるような環境 的な配慮が重要である．図 1 の棈円で囲んだ領域で示す脳波が，知 的生産性が高い状態を反映すると仮定した.

今回は， $\alpha$ 波帯域率（= $\alpha$ 波 $(\alpha$ 波 $+\beta$ 波 $)$ ) 指標とし, 輝度が高すぎても, 低すぎてもその值は低下すると仮定した。

一方， $\alpha$ 波は「覚醒レベル」に影響され，特にLow $\alpha$ 波は眠い状 態でも出現する.このため, 今回は主観評価を併用して営醒度を把 握した.

\section{2 連続一位加算作業}

異なる照明器具条件下で連続一位加算作業を行うと, 照明器具の 輝度が適切な場合, そうでないときよりも解答数が高いと仮定し た.

\section{3. 実験}

\section{1 実験条件}

(1) 照明状態

オフィスの執務エリアを想定して, 机上面照度は $750 \mathrm{~lx}$ 前後にな るよう, 調光装置で照明器具の光束を調整した. 結果, 照明器具周 辺の天井面輝度は, 実際の部屋に近い $50 \mathrm{~cd} / \mathrm{m}^{2}$ となった。

使用した蛍光ランプは昼白色の Hf 高周波点灯専用ランプであ

り，色温度のメーカー公表值は $5,000 \mathrm{~K}$ であった。

使用した照明器具輝度は以下の 4 種類であった. カッコ内は, 鈶 直角 80 度での平均輝度をあらわす。

CRT 型 V2 $\left(200 \mathrm{~cd} / \mathrm{m}^{2}\right), \quad \mathrm{SP}$ 型 $\left(3,200 \mathrm{~cd} / \mathrm{m}^{2}\right)$, 白色仕上げル 一バ付グレア規制型 $\left(6,000 \mathrm{~cd} / \mathrm{m}^{2}\right)$ ，下面開放型 $\left(20,000 \mathrm{~cd} / \mathrm{m}^{2}\right)$ (2)被験者

25〜 51 歳（平均： 36 歳，標準偏差：7.4 歳）の男子 10 名を被験 者とした.

(3)指示事項

実験者は, 被験者に以下のような指示を与えた。

(a)あらかじめ，生活リズムを整える.

(b)前夜，深酒をしない。早めの就寝をする.

(c)実験当日の食事は, 実験時刻に対して余裕を見て取る. 食事後, 休息を十分に取る.

(4)実験時刻

各被験者について，1 日に 2 条件ずつ，2 日間で実験を行った.

2 日とも, サーカディアンリズムを考慮して同じ時刻帯で, 実験 を行った。 (10-12 時あるいは 15-17 時)

(5)照明器具の呈示順

4 種類の照明器具の呈示順は, 順序の影響を相殺するために力ウ ンターバランスをとって配置した。

(6)連続一位加算作業

連続一位加算作業の概要を図 2 に示す。被験者は, 設定した時間 内で隣り合った数值を加算し，その一位の数字をそれらの中間下に 記入した.

\section{2 実験設備}

防音シールド室内に, 異なる輝度の照明器具を設置できる設備を 設けた. 平面図を図 3 に, 側面図を図 4 に示す. 照明器具の輝度は, 反射板を交換することで変更した.

防音シールド室の気温は $27.5^{\circ} \mathrm{C}$, 相対湿度は $60 \%$ であった.

脳波の測定部位は, 前頭部 $\mathrm{Fz}$, 中心部 $\mathrm{Cz}$, 頭頂部 $\mathrm{Pz}$ であった。

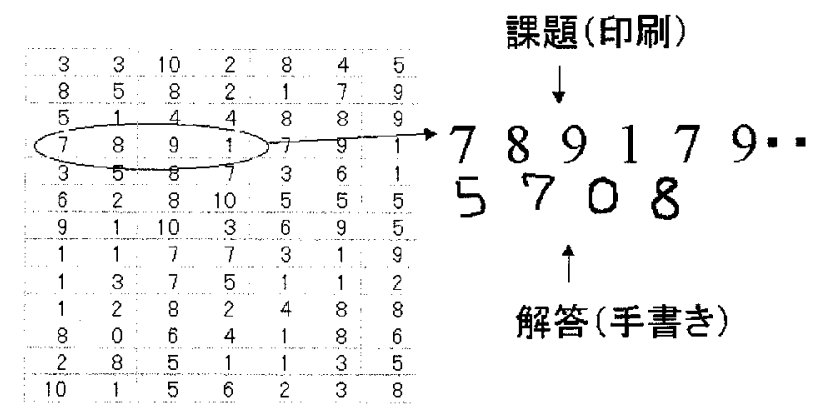

A4用紙

\section{図 2 連続一位加算作業用紙}

Fig.2 Continuous first place addition test form.

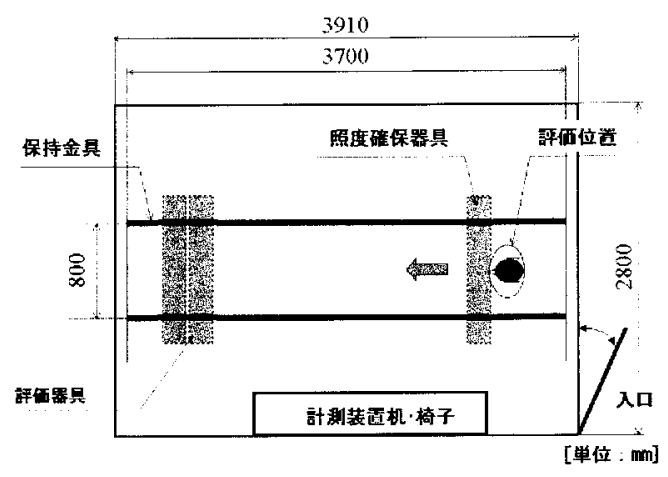

図 3 実験室平面図

Fig.3 Plane figure of the experimental room.

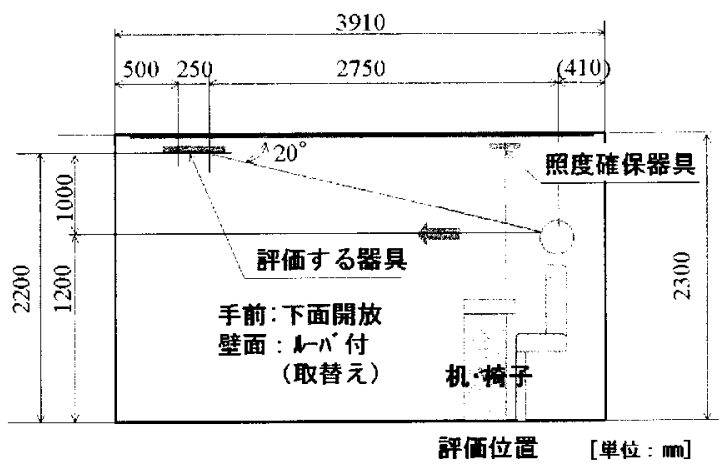

図 4 実験室側面図

Fig.4 Side figure of the experimental room.

\section{3 実験手順}

実験の手順は, 被験者には，3 分間安静閉眼で待機し，その後 照明器具を 3 分間直視, 3 分間安静開眼, 15 秒直視, 1 分間連続 一位加算作業, 15 秒直視, 1 分間連続一位加算作業, 15 秒直視, 4 分間連続一位加算作業を指示した. 


\section{4 主観評価}

生理評価と同時に実施した主観評価の尺度を図 5 に示す．照明 器具のまぶしさの程度, その快, 不快感, 覚醒度, そのときの気 分などをビジュアルアナログスケール(VAS)法で測定をした.

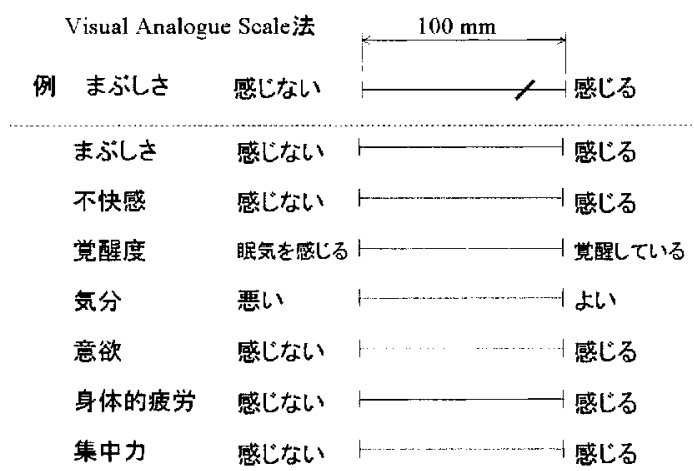

図 5 主観評価項目と尺度

Fig.5 Scale of the subjective appraisal.

\section{5 脳波の測定と解析}

脳波は生体電気用アンプ Neurotop（(登録商標） MME-3124, 日本光電工業社製) で増幅し，サンプリング周波数 $100 \mathrm{~Hz}$ にて $\mathrm{AD}$ 変換の後, MP-150 (BIOPAC Systems, Inc.製) でコンピュ 一夕に記録した。

記録した脳波は，高速フーリ工変換 $(\mathrm{FFT})$ によって周波数成分 に変換した (AcqKnowledge v3.7.3((登録商標) BIOPAC Systems, Inc.製)。得られたパワースペタトルから， $\alpha$ 波， $\beta$ 波の帯域成分 を積分することで, 被験者別の $\alpha$ 波帯域率を求めた.

心理評価, 生理評価, 連続一位加算作業の統計処理については, StatView（(登録商標)Abacus Concepts, Inc.製）を用いて照明器 具を要因とする反復測定分散分析を行った.

\section{4. 結果}

\section{1 主観評価}

主観評価結果の平均值を図 6 に示す。エラーバーは，標準鿁差 を示す.

照明器具のまぶしさの評価結果を図 6 （a）に示す．CRT 型, SP 型は, 他の白色仕上げ照明器具よりはまぶしさ感を感じにく いという評価が得られた，実験中の覚醒度の評価を図 6 (b) に示 す、主観評価上, 被験者の覚醒度は維持されており, 実験結果と しての $\alpha$ 波の出現度が,「眠気に起因するものである」とは断定で きないと思われる。

不快グレアの評価を図 6 (c) に示す，下面開放型は，不快感が 高い。実験中の被験者の疲労感の評価を図 6(d) に示す。疲労感 は無かったと判断される.

\section{2 生理評価}

安静閉眼から目をあけ器具を 8 秒間直視したときの前頭部 $\mathrm{Fz}$ における $\alpha$ 波帯域率の平均值の内，明らかに他の被験者とは異な る脳波のレベルを記録した 1 名をのぞいた 9 名の平均值を, 図 7 に示す.エラーバーは, 標準誤差を示す.

図 7 は，CRT 型のように輝度が低すぎる場合，および下面開放 型のように輝度が高すぎる場合と比較して，SP 型の $\alpha$ 波帯域率 が高い逆 U 字の形になり，仮説立証の可能性が示唆された。この
分散分析結果の危険率は 0.27 であった。
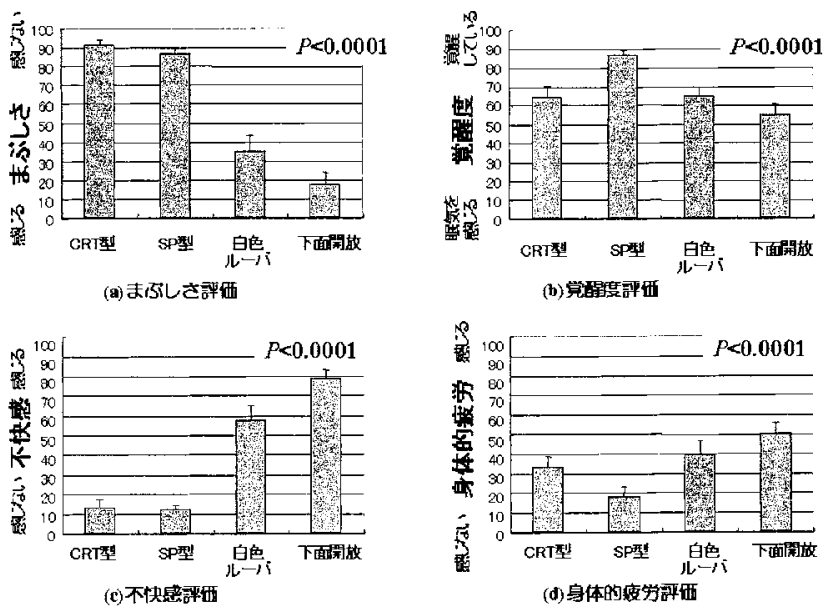

エラーバーは、+標隼䛊差

图 6 主観評価結果

Fig6. Results of the subjective appraisal.

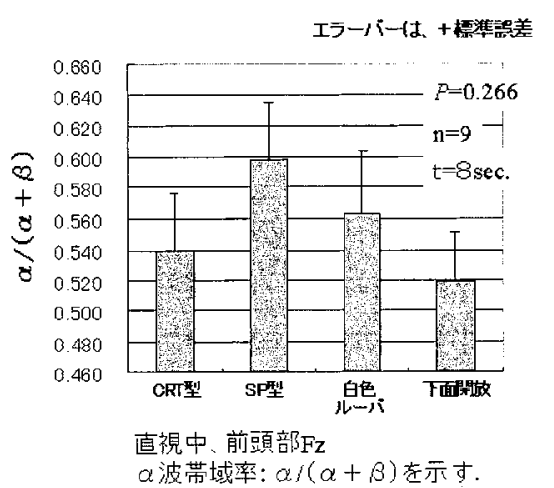

\section{図 7 脳波による生理評価結果}

Fig7. Results of the physiological appraisal.

\section{3 連続一位加算作業}

実験の習熟度合いを向上しきれないで評価を行った結果, 他の被 験者とはまったく異なる傾向を示した一名を除いた 9 名の平均值に よる連続一位加算作業の解答数を図 8 に示す。

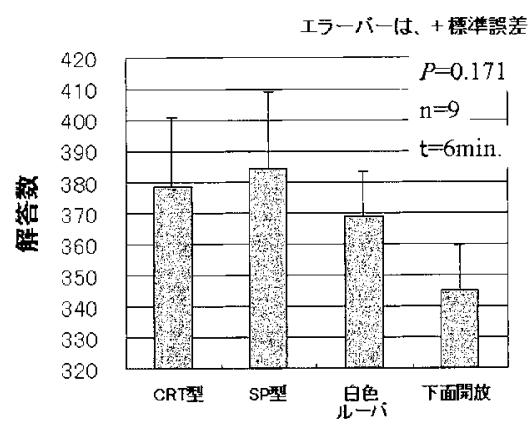

\section{図 8 連続一位加算作業評価結果}

Fig8. Result of continuous first place addition test 
図 8 は, CRT 型のように輝度が低すぎる場合，および下面開放型 のように輝度が高すぎる場合と比較して, OA 型と SP 型の解答数が 多い可能性が示唆された．この分散分析結果の信頼性を示す危険率 は 0.17 であった．照明器具の輝度により, 網膜に残像が残る。この 程度の過多により決まると考えられる。

\section{5. 結論}

通常, 統計的に用いられる危険率 $(p<0.05)$ には至らなかつた(脳波 $p=0.27$, 連続一位加算作業 $p=0.17)$. しかし, 絶対的な厳しさを 要求される場合は別として，幅広く有用性を探す実験における危険 率は 0.1 あるいは 0.25 が採用さ扎ても良い6)という文献もあり，今 回報告をした。

心理評価の結果と，脳波（ $\alpha$ 波带域率），連続一位加算作業の結果 ともに一致した．また，不快グレア防止の見地では照明器具の輝度 は低い方がよいものの，あまり低すぎると逆の傾向を示す可能性が あることも示唆された.

オフィス環境としての照明器具にはちょうど良い明るさレベル （グレアレベル）がある. 知的作業を行う光環境には，適切にグレ アコントロールされた器具を選ぶことが重要である.

\section{参考文献}

(1) ハンス・ユンゲル・ヘンチェル著, 森礼於訳:光と照明, 日本理 工出版会, p.265（1995）

（2）杉本賢：照明環境要素の生体への影響に関する研究一照度と生 理的負担の関係(その 2)，照学誌，65-4, pp.41-45（1981）

（3）佐藤仁人, 当摩, 中山, 高橋：執務空間における照度の生理 • 心理的影響, 照学誌, 80-5, pp.331-338 (1996).

（4）坂上, 明石, 梅野，八木：作業者の集中度と照明環境との関倸 についてー周边の照度／作業エリア, 照学誌, 81-5, pp.385-391 (1997).

（5）宮田洋監修:新生理心理学 1, 北大路書房, p.90（1998）.

(6) StatView 統計編, SAS Institute Inc. , p.77(1998).

(受付 2004 年 11 月 25 日/採録日 2005 年 2 月 4 日)

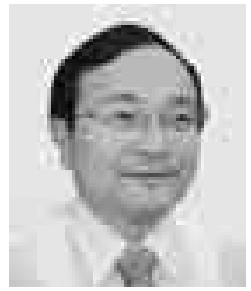

松島 公嗣 (正会員)

松下電工株式会社

干571-8686 大阪府門真市大字門真 1048 1952 年 10 月 8 日生まれ. 1975 年 3 月愛媛大 学工学部電気工学科卒, 同年 4 月松下電工株 式会社に入社，現在，照明事業本部中央照明 エンジニアリング綜合部で照明ソフト開発に 従事. 日本照明委員会会員. 2001 年技術士(電気電子部門).

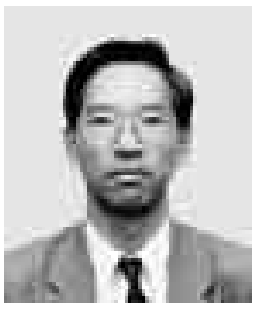

片山＼cjkstart就司（専門会員)

松下電工株式会社

干571-8686 大阪府門真市大字門真 1048

1958 年 4 月 17 日生まれ. 1983 年 3 月京都大 学工学部建築学科修士課程修了, 同年 4 月松下 電工株式会社に入社, 現在, 照明事業本部中央 照明エンジニアリング綜合部で照明ソフト開 発に従事. 日本照明委員会, 日本建築学会会員. 一級建築士.

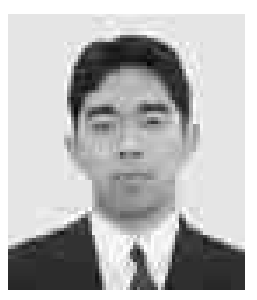

高橋 良香 (正会員)

千葉大学大学院自然科学研究科

干263-8522 千葉市稻毛区弥生町 1-33

1977 年 1 月 4 日生まれ。 2001 年 3 月千葉大学 大学院自然科学研究科像科学専攻博士前期課 程修了. 2004 年 4 月千葉大学大学院自然科学 研究科人間環境デザイン科学専攻博士後期課 程入学. 現在, 在学中. 日本視覚学会, 照明学会, 日本色彩学会 各会員.

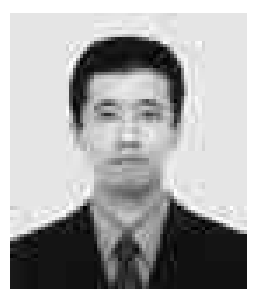

下村 義弘 (非会員)

千葉大学工学部

干263-8522 千葉市稲毛区弥生町 1-33

1972 年 12 月 20 日生まれ. 1995 年 3 月千葉大 学工学部工業意匠学科卒業, 2000 年 3 月千葉 大学博士 (工学) 取得, 同年 4 月より千葉大学 工学部デザイン工学科人間生活工学教室にて 助手として勤務, 現在に至る. 日本生理人類学会, 日本人間工学 会などに所属. 専門はエルゴデザイン, バイオインタフエースな 亡..

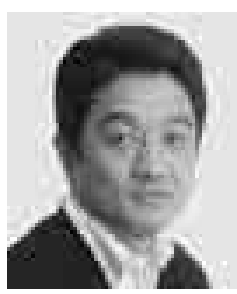

岩永 光一 (非会員)

千葉大学大学院自然科学研究科

于263-8522 千葉市稲毛区弥生町 1-33

1958 年 8 月 5 日生まれ. 1983 年 3 月九州芸術 工科大学大学院芸術工学研究科修士課程生活環 境専攻修了, 同年 5 月九州芸術工大学芸術工学 部助手. その後, 大塚製薬 (株) 研究員, 千某 大学共同研究推進センター助教授等を経て, 1997 年 4 月千葉大学 大学院自然科学研究科助教授, 現在に至る. 博士 (理学) (1993 年, 千葉大学). 日本生理人類学会, 日本人間工学会ほかに所属.

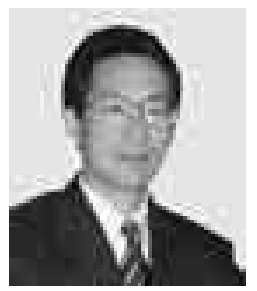

勝浦 哲夫 (非会員)

千葉大学工学部

干263-8522 千葉市稲毛区弥生町 1-33

1950 年 1 月 30 日生まれ. 1974 年 3 月九州芸 術工科大学芸術工学部工業設計学科卒, 1974 年 4 月九州芸術工大学芸術工学部助手, 1980 年 3 月千葉大学工学部講師, 1986 年 6 月同助 教授，1996 年 4 月同教授に昇任し現在に至る. 1986 年理学博士 (京都大学), 日本生理人類学会, 日本人間工学会ほかに所属. 